\title{
Edukasi Perilaku Cuci Tangan Menggunakan Sabun Kepada Pelaku Usaha di Kebonso, RT 01/RW 03, Pulisen, Boyolali, Boyolali
}

\author{
Dimas Ino Asta Rendra ${ }^{\mathrm{a}, 1}$, Sigit Muryanto ${ }^{\mathrm{b}, 2, *}$ \\ ${ }^{a}$ Fakultas Hukum, Universitas Boyolali, Jalan Pandanaran No.405, Boyolali 57315, Indonesia \\ ${ }^{\mathrm{b}}$ Fakultas Pertanian, Universitas Boyolali, Jalan Pandanaran No.405, Boyolali 57315, Indonesia \\ ${ }^{1}$ dimasinoastarendra@gmail.com ${ }^{2}$ sigit.ms2013@gmail.com* \\ * Korespondensi penulis
}

\section{ARTICLE INFO}

Article history

Menerima 18 April 2021

Revisi 15 November 2021

Diterima 30 November 2021

Kata Kunci

Pendidikan

Cuci tangan

Sabun

\section{ABSTRACT}

Washing hands with soap is one way to prevent the spread of the Covid19 virus. Seeing the importance of this, it is necessary to provide education regarding the importance of washing hands properly to the community. Business actors who are the drivers of the economy must understand how to protect themselves from the spread of the Covid-19 virus. In addition, business actors often interact with other people. Seeing the importance of this, the community service team considered it necessary to provide education regarding the importance of washing hands properly. The activity begins with an application for permission to the head of the RT, Kelurahan and Subdistrict. After that, the team asked for permission from the business actor in Kebonso RT 01 RW.03. Pulisen, Boyolali who will be partners in service. Activities are carried out by visiting business actors to provide direct education. After business people understand the importance and how to wash their hands. Then the risk of being exposed to the Covid-19 virus will be smaller and the economy will run well.

This is an open access article under the CC-BY-SA 4.0 license.

\section{Pendahuluan}

Pelaku usaha merupakan penggerak perekonomian negara. Selama pelaku usaha dapat beroperasi, maka roda perekonomian nasional akan berjalan. Ketika pelaku usaha tidak dapat menjalankan usahanya maka akan mengganggu perekonomian nasional. Akhir tahun 2019 tepatnya pada bulan Desember dunia dihebohkan dengan berita munculnya wabah pneumonia yang tidak diketahui sebab pastinya. Wabah ini pertama kali ditemukan di Wuhan Provinsi Hubei China. Kebanyakan pasien pneumonia ini berawal dari pedagang di pasar Huanan yang menjual hewan hidup yang terletak di kota Wuhan. Pada 7 Januari 2020 para peneliti berhasil mengidentifikasi penyebab pneumonia ini yakni jenis novel coronavirus. Secara resmi, WHO menamakan penyakit ini Covid-19 (Corona Virus Disease 2019) dan nama virus tersebut adalah SARS-CoV-2 (severe acute respiratory syndrome coronavirus 2).[1] Virus Corona atau severe acute respiratory syndrome coronavirus 2 (SARS-CoV-2) adalah virus yang menyerang system pernapasan. Penyakit karen virus ini disebut Covid-19. Virus Corona bisa menyebabkan gangguan pada sistem pernafasan, pneumonia akut, sampai kematian. [2] Secara umum, penularan paling efektif virus Corona antar manusia adalah droplet atau cairan yang dikeluarkan saat batuk atau bersin serta yang menempel di benda sekitar. Penularan antar manusia yang terjadi dengan massif membuat pembatasan jarak dan sosial harus dilakukan ketat. Oleh karena itu, upaya preventif perlu dilakukan 
dengan menjaga jarak 1-2 meter. Cairan yang mengandung virus Corona yang keluar melalui batuk atau bersin dapat menempel dibagian mulut atau hidung seseorang, kemudian terhirup saat mengambil nafas dan masuk ke paru-paru. [3]. Selain pencegahan dilakukan dengan menjaga jarak, pencegahan penularan virus Corona juga dilakukan dengan penggunaan masker, mencusi tangan, mengindari kerumunan, dan mengurangi mobilitas.

Pandemi atau epidemi global mengindikasikan infeksi Covid-19 yang sangat cepat hingga hamper tidak ada negara atau wilayah di dunia yang absen dari virus Corona. Peningkatan jumlah kasus terjadi dalam waktu singkat hingga butuh penanganan secepatnya. Hingga kini belum ada obat spesifik untuk menangani kasus infeksi virus Corona atau Covid-19.[4] Setelah penetapan Covid-19 sebagai pandemic global oleh Organisasi Kesehatan Dunia (WHO), pemerintah langsung Menyusun strategi agar penularan virus dapat diminimalisir. Hal tersebut dilakukan mengingat sejak awal kemunculannya hingga kini, jumlah kasus positif Covid-19 kian meningkat.[5] Banyak kerugian yang ditimbulkan dari pandemic ini yang berdampak pada perekonomian Indonesia. Setelah mengalami peningkatan kasus yang melesat dengan kurun waktu yang cepat, pemerintah membuat kebijakan dalam mengatasi pandemic Covid-19 dengan berlakunya PSBB yang tercantum dalam Peraturan Pemerintah No.21 Tahun 2020. Dengan adanya PSBB tersebut semua kegiatan yang biasa dilakukan terpaksa berhenti. Seluruh kegiatan di bidang industri maupun perkantoran untuk sementara waktu terpaksa berhenti untuk beroperasi. Selain itu sektor, pendidikan, layanan publik, seluruh tempat ibadah, pusat perbelanjaan, rumah makan, maupun tempat pariwisata juga mengalami hal yang sama. [6]

Dengan perekonomian yang sedang tidak setabil dan juga pembatasan kegiatan yang dilakukan pemerintah, sedangkan masyarakat tetap harus mencari makan. Hal tersebut harus disikapi dengan benar. Sebagai contoh pelaku usaha sering berinteraksi dengan orang yang tidak diketahui apakah terpapar virus Covid-19 atau tidak, sehingga para pelaku usaha akan lebih beresiko terpapar virus Covid-19. Dengan demikian para pelaku usaha harus mengerti cara mencegah penularan Covid-19 yang salah satunya dengan mencuci tangan dengan benar. Selain itu, dalam Peraturan Bupati Boyolali Nomor. 49 Tahun 2020 tentang Penerapan Disiplin dan Penegakan Hukum Protokol Kesehatan Sebagai Upaya Pencegaha dan Pengendalian Corona Virus Disease 2019 pelaku usaha diwajibkan untuk mentaati protokol kesehatan.[7] Apabila melanggar maka akan diberikan sanksi administratif. Sanksi didefinisikan oleh Kelsen sebagai reaksi koersif masyarakat atas tingkah laku manusia (fakta sosial) yang mengganggu masyarakat. Setiap sistem norma menurut pandangan Kelsen selalu bersandar pada sanksi. Setiap norma dapat dikatakan legal apabila dilekati sanksi, walaupun norma itu harus dilihat berhubungan dengan norma yang lainnya.[8] Sanksi merupakan inti dari penegakan Hukum Administrasi Negara. Sanksi biasanya diletakkan pada akhir setiap peraturan, in cauda venenum (secara Bahasa berati di ujung terdapat racun), artinya di ujung kaidah hukum terdapat sanksi. Sanksi diperlukan untuk menjamin penegakan Hukum Administrasi Negara.[9]

Perlu dikemukakan bahwa keberadaan dan penggunaan sanksi pidana dalam Perda itu sifatnya pelengkap (aanvullen) atau penegas terutama ketika sanksi administratif dipandang kurang efektif atau kurang maksimal dalam menopang tegaknya norma-norma dalam Perda. Dengan ungkapan lain sifat sanksi administratif dalam Perda adalah premium remedium, sedangkan sanksi pidana bersifat ultimatum remedium. [10]

Melihat pentingnya hal tersebut, Tim Pengabdian KKN Universitas Boyolali memberikan edukasi cara mencuci tangan sesuai protokol kesehatan, yaitu mencuci tangan menggunakan sabun. Kegiatan dilaksanakan dari tanggal 21 Februari 2021 sampai dengan tanggal 31 Maret 2021 di Dusun Kebonso RT 01 / RW 03, Pulisen, Boyolali, Boyolali. Kegiatan dilaksanakan dengan cara mendatangi tempat usaha dari para pelaku usaha.

\section{Metode}

Program Kegiatan diawali dengan permohonan izin kepada Ketua RT, Keluranah dan Kecamatan. Selanjutnya Tim meminta izin kepada Pelaku usaha di lingkungan Dusun Kebonso, RT 01 / RW 03, Pulisen, Boyolali, Boyolali selaku mitra pengabdian. Kegiatan KKN ini dilakukan di 
rumah makan di lingkungan Dusun Kebonso, RT 01 RW 03, Pulisen, Boyolali, Boyolali dengan mengajarkan bagaimana cara cuci tangan menggunakan sabun kemudian diikuti oleh semua karyawan rumah makan. Dalam cara-cara mencuci tangan yang baik dan benar terdapat 6 langkah, diantaranya ialah: memulai cuci tangan dari bagian depan telapak tangan, laku lanjut ke belakang bagian tangan, selasela jari, buku-buku jari, lalu kuku-kuku jari dan kemudain jempol dan terakhir adalah pergelangan. Lalu basuh menggunakan air bersih yang mengalir. Serta tahap simulasi kegiatan ini dilaksanakan di rumah makan dengan melasanakan praktik cuci tangan menggunakan sabun dibawah air mengalir. Semua pelaku usaha mempraktekkan dengan baik dan benar.Kegiatan tersebut dilakukan selama program KKN mulai dari tanggal 21 Februari 2021 sampai dengan tanggal 31 Maret 2021.

\section{Hasil dan Pembahasan}

Kegiatan pengabidan masyarakat dalam bentuk "Edukasi Perilaku Cuci Tangan Menggunakan Sabun" Adapun hasil (output) yang diharapkan dari kegiatan ini adalah: Kegiatan sebagai sosialisasi dengan memberikan penyuluhan dan simulasi cuci tangan pakai sabun. Pada tahap ini dilakukan pengurusan izin ke pihak RT dan pemilik kegiatan usaha kemudian menetapkan waktu pelaksanaan dan disepakati melaksanakan kegiatan tersebut. Dengan simulasi atau langsung praktek cara cuci tangan memakai sabun dibawah air mengalir yang dilaksanakan. Simulasi ini dilakukan oleh tim pengabdian masyarakat dengan berpedoman pada 6 langkah mencuci tangan. Satu per satu pelaku usaha didampingi untuk mencuci tangan memakai sabun sampai mereka mampu melakukan dengan baik dan benar. Kegiatan simulasi Cuci Tangan Pakai Sabun (CTPS) adalah salah satu tindakan sanitasi dengan membersihkan tangan dan jari-jemari menggunakan sabun sehingga menjadi bersih.[11] Cuci tangan menggunakan air bersih dan sabun merupakan bagian dari indikator perilaku hidup bersih dan sehat (PHBS) dalam keluarga. Keluarga diberdayakan sebagai sasaran awal penerapan pola hidup bersih dan sehat.[12] Mencuci tangan dengan air dan sabun merupakan langkah kecil untuk memiliki hidup sehat. Perilaku sederhana ini bisa melindungi kita dari penyakit diare dan saluran pernapasan. Banyak penyakit infeksi dimulai dengan sentuhan dengan tangan yang terkontaminasi dengan organisme.[13] Melalui Kegiatan ini dilakukan di rumah makan atau tempat pelaku usaha masing-masing dengan mengajarkan cara cuci tangan pakai sabun Menurut WHO, terdapat 6 cara melakukan cuci tangan yang benar yaitu: [14]

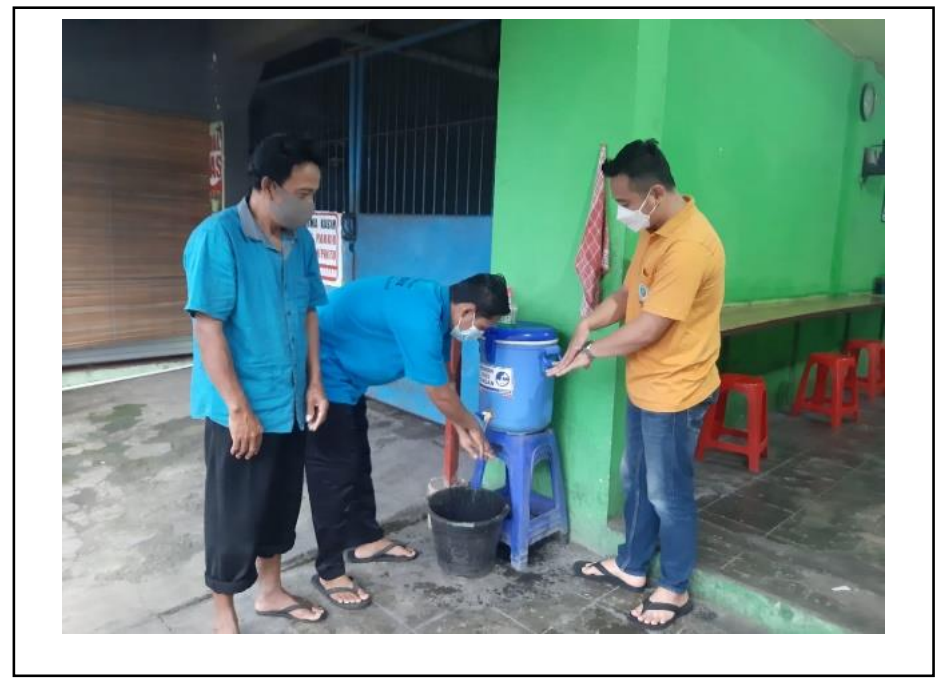

Fig 1. Mencuci Tangan dengan Sabun

- Menuangkan handwash pada telapak tangan, kemudian mengusap dan menggosok kedua telapak tangan dengan lembut dengan arah memutar;

- Mengusap dan menggosok kedua punggung tangan secara bergantian;

- Menggosok sela-sela tangan hinggah bersih;

- Membersihkan semua ujung jari secara bergantian dengan posisi saling mengunci;

- Menggosok dan memutar kedua ibu jari secara bergantian; 
- Meletakkan ujung jari di telapak tangan lalu diputar-putar sampai bersih.

Selain untuk mencegah penyebaran Covid-19, mencuci tangan dengan benar juga dapat mencegah penularan penyakit seperti diare, kolera, disentri, typhus, kecacingan, penyakit kulit, Infeksi Saluran Pernapasan Akut (ISPA).[15] Dengan adanya edukasi tentang cara mencuci tangan pakai sabun terhadap pelaku usaha di Dusun Kebonso, RT 01 / RW 03, Pulisen, Boyolali, Boyolali dapat mengurangi resiko penularan Covid-19 kepada pelaku usaha. Sehingga para pelaku usaha bisa terus melakukan kegiatan usaha dengan aman.

\section{Kesimpulan}

Pandemi COVID-19 adalah peristiwa menyebarnya penyakit Virus Corona. Pandemi ini telah menyebabkan gangguan sosial ekonomi global termasuk di Indonesia tentunya. Dalam usaha pengabdian masyarakat, kami membantu pelaku usaha dalam bentuk penerapan cuci tangan menggunakan sabun dengan baik dan benar. Dengan mencuci tangan dengan benar akan mengurangi resiko terpapar virus Covid-19. Selain itu penerapan protokol kesehata yang salah satunya mencuci tangan pakai sabun merupakan kuajiban dari pelaku usaha yang sudah diatur dalam Peraturan Bupati Boyolali Nomor. 49 Tahun 2020 tentang Penerapan Disiplin dan Penegakan Hukum Protokol Kesehatan Sebagai Upaya Pencegaha dan Pengendalian Corona Virus Disease 2019.

\section{Ucapan Terima Kasih}

Kami panjatkan syukur Alhamdulillah kepada Allah SWT yang telah memberikan rahmat dan hidayah Nya sehingga segala sesuatunya selalu diberikan kelancaran. Tidak lupa pula kami ucapkan terima kasih kepada Civitas Universitas Boyolali, Dosen Pembimbing Lapangan KKN, Orang tua dan istri saya yang selalu membantu dalam pelaksanaan program KKN ini, serta semua pihak yang tidak dapat kami sebutkan satu-persatu yang telah memberikan bantuan dalam bentuk apapun sehingga kegiatan KKN ini dapat terlaksana dan selesai dengan baik.

\section{Daftar Pustaka}

[1] Y. Levani, A. D. Prastya, S. Mawaddatunnadila, K. Wuhan, and P. Huebei, "Coronavirus Disease 2019 ( COVID-19 ): Patogenesis , Manifestasi Klinis dan Pilihan Terapi," vol. 2019, 2019.

[2] S. Kharismatul, Metha, Ekanita, "Edukasi Dan Evaluasi Tingkat Pengetahuan Warga Sekitar Masjid Di Daerah Pekalongan Barat Mengenai Penggunaan Handsanitizer Guna Pencegahan Covid-19," J. Abdimas, vol. 2, no. 1, p. 9, 2021.

[3] Etriyani,Dkk. Mencegah Penularan Virus Corona., "Jurnal Abdimas Saintika," 2020.

[4] Sri Handayani Sagala,,"Jurnal Menara Medika,Hubungan Pengetahuan Dan Sikap Masyarakat Terhadap Covid-19, https://jurnal.umsb.ac.id/index.php/menaramedika/index JMM 2020 p-ISSN 2622-657X, e-ISSN 2723-6862,” vol. 3, no. 1, pp. 46-53, 2020.

[5] I Nyoman Artayasa"Kebijakan Pemerintah Dalam Percepatan Penanganan Dampak Covid19 Dikota Denpasar. Cakrawati," vol. 03, no. 02, pp. 34-39, 2019.

[6] F. R. Yamali and R. N. Putri, "Dampak Covid-19 Terhadap Ekonomi Indonesia," vol. 4, no. September, pp. 384-388, 2020, doi: 10.33087/ekonomis.v4i2.179.

[7] Peraturan Bupati Boyolali.Nomor 49 Tahun 2020 Tentang Penerapan Disiplin Dan Penegakan Hukum Prostol kesehatan Sebagai upaya pencegahan dan mengendalian corana virus disease 2019

[8] Antonius Cahyadi dan E. Virnando M.Manullang.Pengantar Filsafat Hukum. Jakarta: Kencana Prenada Media Group. 2007.

[9] Ridwan.HR,Hukum Administrasi Negara, Edisi revisi. Jakarta: Rajawali Pers, 2014.

[10] Ridwan, Hukum Administrasi Didaerah, Edisi Pertama.Yogyakarta: FH UII Press, 2009.

[11] S.Sdn, B. Parang, and K, Jeneponto, “JURNAL NASIONAL ILMU KESEHATAN ( JNIK )," vol. 1, pp. 1-9, 2018.

[12] P. Asda, N. Sekarwati, S. Tinggi, I. Kesehatan, and W. Husada, "Jurnal Media Keperawatan: Politeknik Kesehatan Makassar Jurnal Media Keperawatan: Politeknik Kesehatan Makassar," vol. 11, no. 01, pp. 1-6, 2020.

[13] K. Friskarini and T. R. Sundari, "Pelaksanaan Cuci Tangan Pakai Sabun ( Tantangan dan 
Peluang) Sebagai Upaya Kesehatan Sekolah di Sekolah Dasar Negeri Kecamatan Bogor Utara Kota Bogor Implementation of Handwashing with Soap ( Challenges and Opportunities ) as A School Health Effort of Ele," J. Ekol. Kesehat., vol. 19, no. 1, pp. 2134, 2020.

[14] G. T. Tulak, S. Ramadhan, and A. Musrifah, "Edukasi Perilaku Cuci Tangan Pakai Sabun Pada Siswa Untuk Pencegahan Transmisi Penyakit," JMM (Jurnal Masy. Mandiri), vol. 4, no. 1, p. 37, 2020, doi: 10.31764/jmm.v4i1.1702.

[15] Vevi Suyenti,Dkk. C. Mencuci, T. Yang, and B. Dan, "PENCEGAHAN PENYEBARAN COVID-19," vol. 1, no. 1, pp. 25-32, 2020. 